Article

\title{
Biodegradation Potential and Diversity of Diclofenac-degrading Microbiota in an Immobilized Cell Biofilter
}

\author{
Efstathia Navrozidou ${ }^{1}$, Nikolaos Remmas ${ }^{1}$, Paraschos Melidis ${ }^{1}$, Dimitrios G. Karpouzas ${ }^{2}$, \\ George Tsiamis ${ }^{3}(\mathbb{D})$ and Spyridon Ntougias $1, *(\mathbb{D})$ \\ 1 Laboratory of Wastewater Management and Treatment Technologies, Department of Environmental \\ Engineering, Democritus University of Thrace, Vas. Sofias 12, 67132 Xanthi, Greece \\ 2 Laboratory of Plant and Environmental Biotechnology, Department of Biochemistry and Biotechnology, \\ University of Thessaly, Biopolis, 41500 Larissa, Greece \\ 3 Department of Environmental Engineering, University of Patras, 2 Seferi St., 30100 Agrinio, Greece \\ * Correspondence: sntougia@env.duth.gr; Tel.: +30-25410-79313
}

Received: 22 July 2019; Accepted: 17 August 2019; Published: 22 August 2019

check for updates

\begin{abstract}
Despite that diclofenac has been embodied to the European watch list of priority substances of concern, studies on diclofenac biodegradation are limited and the diversity of diclofenac-degrading microbiota remains unknown. In this work, an immobilized cell biofilter was constructed and operated to evaluate its effectiveness to depurate high strength diclofenac wastewater and to identify the diclofenac-degrading community accommodated in activated sludge by employing high-throughput sequencing techniques. After a two-month adaptation period, biofilter removal efficiencies reached values as high as $97.63 \pm 0.62 \%$, whereas utilization of diclofenac in the immobilized cell biofilter led to a drastic $\mathrm{pH}$ decrease. Based on Illumina sequencing, the major bacterial taxa identified in the immobilized cell biofilter were members of the species Granulicella pectinivorans and Rhodanobacter terrae, followed by members of the species Castellaniella denitrificans, Parvibaculum lavamentivorans, Bordetella petrii, Bryocella elongata and Rhodopseudomonas palustris. The ability of such taxa to utilize a wide range of carbon sources and to effectively adapt under acidic conditions seemed to be the main parameters, which favored their prevalence in the immobilized cell biofilter. In addition, Wickerhamiella was the predominant fungal taxon in the immobilized cell biofilter, which appears to be actively involved in diclofenac degradation in activated sludge systems.
\end{abstract}

Keywords: priority substances; pH acidification; wastewater treatment; Granulicella; Rhodanobacter; Wickerhamiella

\section{Introduction}

The detection of non-steroidal anti-inflammatory drugs (NSAIDs) in aquatic environments is a result of various sources of pollution, exhibiting a negative impact on health and the environment. In particular, pharmaceuticals are disposed of households, veterinary clinics, hospitals and pharmaceutical manufacturing facilities and enter wastewater treatment plants (WWTPs) for processing prior to their final environmental discharge in natural water resources. However, WWTPs are designed mainly to remove conventional pollutants contained in municipal and industrial wastewater and fail to effectively remove NSAIDs [1,2], a fact that has led to the detection of numerous pharmaceuticals in the effluents of WWTPs as well as in surface water and groundwater systems $[3,4]$.

Diclofenac [2-(2,6-dichloranilino) phenylacetic acid] is one of the best-selling NSAIDs worldwide [5]. It is a common environmental contaminant regularly detected in drinking water, river 
freshwater and groundwater [6-10]. This along with its documented effects on endocrine systems of humans and on animal reproduction has led the European Commission to include diclofenac in the first watch list of priority substances of concern [11,12]. Toxic effects of diclofenac on bacteria, algae, microcrustaceans and fish have been also reported at concentrations similar to those measured in aquatic habitats [13]. The chronic use of this emerging contaminant can further intensify the negative consequences to ecosystems [14]. Diclofenac toxicity is not limited to aquatic organisms, but also to wildlife via the consumption of contaminated freshwater, like in the case of the oriental white-backed vultures, which suffered a 95\% depletion in their population, due to the widespread presence of this pollutant to the surface water [15].

Diclofenac, as other pharmaceuticals, is not effectively removed by conventional WWTPs, a consequence of its large quantities consumed and its low biodegradation potential $[4,16,17]$. Diclofenac concentration usually ranges between 0.01 and $510 \mu \mathrm{g} / \mathrm{L}$ in the influent of municipal WWTPs [18]. However, experiments with 30 to $50 \mathrm{mg} / \mathrm{L}$ have been performed to simulate diclofenac removal from hospital wastewater $[19,20]$. Lonappan et al. [17] reported that diclofenac removal efficiencies ranged from $30 \%$ to $70 \%$ in activated sludge systems. In a study performed in 15 Portuguese WWTPs, diclofenac removal efficiencies did not exceed $46 \%$ [21]. Similarly, Behera et al. [22] reported diclofenac average removal efficiency of $68 \%$ in six WWTPs. Even in the use of non-conventional wastewater treatment configurations, like membrane bioreactors (MBR), residual diclofenac concentrations greater than $50 \%$ have been determined [23]. Gurung et al. [24] also reported diclofenac removal efficiency of $38 \%$ in an MBR system operating under low temperatures in the Nordic region.

Despite the importance of degrading NSAIDs, scientific findings on diclofenac biodegradation are limited. Such reports include the isolation of a Brevibacterium sp. (strain D4) from activated sludge, which was proved partially capable of utilizing diclofenac (by 35\%) as the sole carbon source [25]. A Labrys portucalensis strain F11 isolated from polluted sediment was capable of completely degrading diclofenac co-metabolically in the presence of acetate [26]. Moreover, the biodegradation potential of diclofenac was investigated through the cultivation of the white-rot fungus Phanerochaete chrysosporium in batch bioreactors, reporting complete removal of this pharmaceutical within a day [27].

In this study, an immobilized cell biofilter was installed and operated for an extended time period under diclofenac selection pressure to favor the enrichment of the diclofenac-degrading microbiota that are present in the activated sludge. This set up allowed us to investigate the effectiveness of this biofilter for the depuration of high strength diclofenac wastewater and to identify the diclofenac-degrading microbial community accommodated in the activated sludge through the implementation of high-throughput sequencing techniques.

\section{Materials and Methods}

\subsection{Diclofenac-Based Wastewater Composition}

The diclofenac-based wastewater consisted of $400 \mathrm{mg} / \mathrm{L}$ diclofenac sodium salt (J\&K Scientific, Beijing, China, $97 \%$ purity), containing $4 \mathrm{mM} \mathrm{NH}_{4} \mathrm{Cl}, 0.2 \mathrm{mM} \mathrm{NH}_{4} \mathrm{Fe}\left(\mathrm{SO}_{4}\right)_{2} \cdot 6 \mathrm{H}_{2} \mathrm{O}, 0.5 \mathrm{mM} \mathrm{Na}_{2} \mathrm{HPO}_{4}$, $5 \mathrm{mM} \mathrm{KCl}, 2 \mathrm{mM} \mathrm{MgSO} \cdot 7 \mathrm{H}_{2} \mathrm{O}, 2 \mathrm{mM} \mathrm{CaCl} 2 \cdot 2 \mathrm{H}_{2} \mathrm{O}, 3 \mu \mathrm{M} \mathrm{NiCl} \cdot 6 \mathrm{H}_{2} \mathrm{O}, 1 \mu \mathrm{M} \mathrm{Na} \mathrm{SeO}_{3}, 3 \mu \mathrm{M}$ $\mathrm{CoCl}_{2} \cdot 6 \mathrm{H}_{2} \mathrm{O}, 3 \mu \mathrm{M} \mathrm{NaMoO} \cdot \cdot 2 \mathrm{H}_{2} \mathrm{O}, 2 \mu \mathrm{M} \mathrm{ZnSO}_{4} \cdot 7 \mathrm{H}_{2} \mathrm{O}$ and $1 \mu \mathrm{M} \mathrm{H}_{3} \mathrm{BO}_{4}$ [28]. No organic solvent, i.e., methanol, was used, so the $\mathrm{pH}$ of the wastewater was initially increased to 8 and then readjusted to 7 to increase the solubility of the pharmaceutical added.

\subsection{Bioreactor Configuration}

An immobilized cell biofilter of $0.5 \mathrm{~L}$ working volume was setup, consisting of a cylindrical bioreactor and a 0.12 L-glass tube for aeration (Figure 1). The main bioreactor was filled with Siran beads, forming a $0.15 \mathrm{~L}$ Siran-based column in order to immobilize microbial biomass. At the bottom of the glass tube, an appropriate air pump was connected, providing adequate oxygen to microbial cells by recirculating the liquid medium from the main bioreactor to the air diffuser-containing tank 
through the operation of a $33 \mathrm{~L} / \mathrm{h}$ peristaltic pump. The diclofenac-based wastewater was introduced to the biofilter by a liquid pump, so as a hydraulic retention time (HRT) of 3.5 days was achieved. During start-up, the immobilized cell biofilter was inoculated with activated sludge from a local full-scale WWTP.

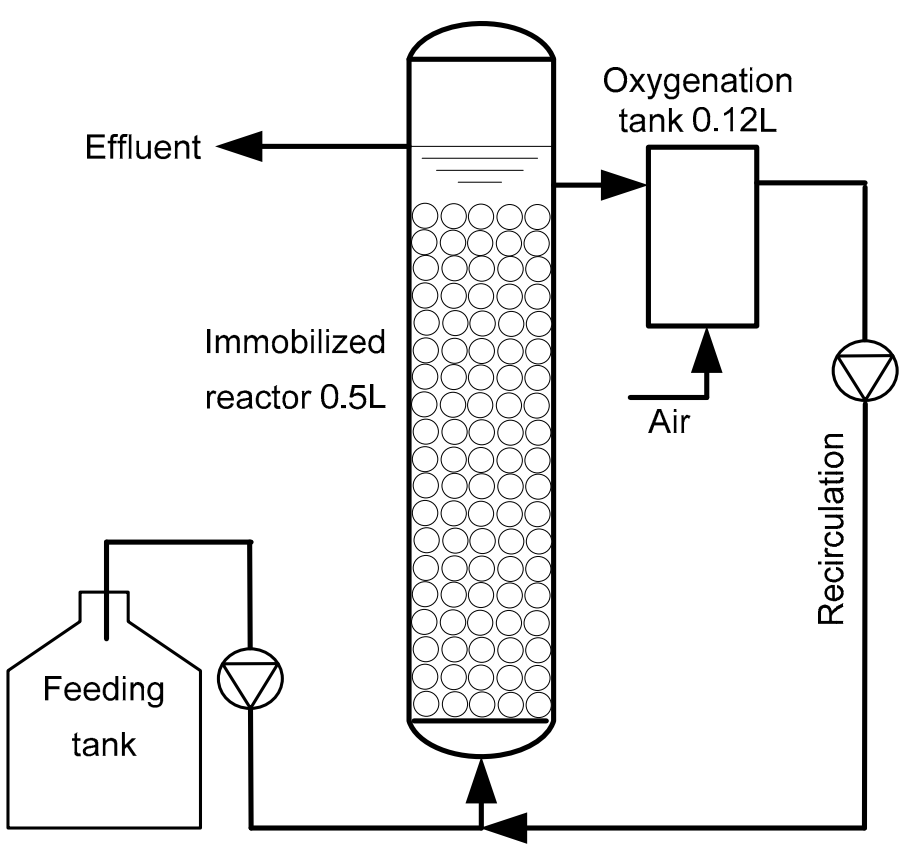

Figure 1. Schematic illustration of the immobilized cell biofilter treating diclofenac-based wastewater.

\subsection{Physicochemical Analyses}

Dissolved oxygen (DO) was recorded by using a WTW Oxi $320 \mathrm{~m}$, whereas $\mathrm{pH}$ and electrical conductivity (EC) were measured by using the Metrohm 632 and Crison CM35 probe apparatus, respectively. Chemical oxygen demand (COD) and biochemical oxygen demand (BOD5) were determined according to the "Standard Methods for the Examination of Water and Wastewater" [29]. Physicochemical parameters were determined on regular basis, e.g., three times per week for $\mathrm{pH}$, EC and COD. Total kjeldahl nitrogen (TKN) and ammonium nitrogen $\left(\mathrm{NH}_{4}{ }^{+}-\mathrm{N}\right)$ measurements were performed through the implementation of the Kjeldahl and the ammonium distillation protocol, respectively. To measure $\mathrm{NO}_{3}{ }^{-}-\mathrm{N}$ concentration, nitrates were reduced to nitrites through filtration in a Cd-copperized column and subsequently nitrite nitrogen $\left(\mathrm{NO}_{2}{ }^{-}-\mathrm{N}\right)$ was determined spectrophotometrically at $543 \mathrm{~nm}$ as previously described by Clesceri et al. [29]. Determination of orthophosphates as $\mathrm{PO}_{4}{ }^{3-}-\mathrm{P}$ was performed through the reduction of the molybdophosphoric acid, deriving from the reaction of orthophosphates with ammonium molybdate under acidic conditions, by stannous chloride solution.

\subsection{HPLC Determination of Diclofenac}

Prior to the analysis, samples from the influent and the effluent of the biofilter system obtained every 5 to 6 days were dissolved in methanol at concentrations of 1:100 and 1:5 v/v, respectively and passed through $0.45 \mu \mathrm{m}$ membrane filters. A Shimadzu SCL-10AVP HPLC system (Kyoto, Japan), consisting of a Discovery HS C18 column $(5 \mu \mathrm{m}, 250 \times 4.6 \mathrm{~mm}$ ) (Supelco, Bellefonte, PA, USA), a LC-10 ADVP pump, a DGU-14A degassing system, a CTO-10ASVP column oven and a SPD-M10 AVP photodiode array detector was used for the chromatographic determination of diclofenac. The mobile phase consisted of a mixture of acetonitrile and $0.2 \%$ formic acid in water at mixing ratio of $60: 40 \mathrm{v} / \mathrm{v}$. The flow rate was $0.8 \mathrm{~mL} / \mathrm{min}$, the injection volume was $20 \mu \mathrm{L}$ and the calibration standards or samples were analyzed by applying an isocratic elution program at $80 \mathrm{bar}$ and $30^{\circ} \mathrm{C}$ for a period of $20 \mathrm{~min}$. 
Photodiode array detection of diclofenac was performed at $200 \mathrm{~nm}$ and the limit of detection was $250 \mu \mathrm{g} / \mathrm{L}$.

\subsection{Amplicon Sequencing Analysis of the Diclofenac-degranding Microbiota in the Immobilized Cell Biofilter}

Samples for amplicon sequencing analysis were obtained under steady state conditions. Genomic DNA was extracted in triplicates from the Siran beads containing immobilized biomass through the use of "Wizard Genomic DNA Purification Kit" (Promega, Madison, WI, USA), based on the instructions recommended by the manufacturer. In detail, the immobilized on Siran glass beads biomass were initially frozen with liquid nitrogen and pestled to dust. DNA extraction for bacterial amplicon sequencing was performed following the "Wizard Genomic DNA Purification Kit" protocol for bacteria, which includes additional steps for DNA extraction from Gram-positive bacteria, where $60 \mu \mathrm{L}$ of $10 \mathrm{mg} / \mathrm{mL}$ lysozyme and $60 \mu \mathrm{L}$ of $10 \mathrm{mg} / \mathrm{mL}$ lysostaphin were added to achieve cell lysis per each sample preparation. The "Wizard Genomic DNA Purification Kit" protocol for DNA extraction from yeasts, which included a lyticase treatment step by adding $7.5 \mu \mathrm{L}$ of $75 \mathrm{U} / \mu \mathrm{L}$ lyticase per sample preparation, was employed. Amplification of the V1-V3 fragment of the 16S rRNA gene was performed by using the primer set 27F (5'-AGR GTT TGA TCM TGG CTC AG-3') and 519R (5'-GTN TTA CNG CGG CKG CTG-3'), whereas amplification of the fungal ITS2 region was performed by primers ITS3F ( $5^{\prime}$-GCA TCG ATG AAG AAC GCA GC-3') and ITS4R ( $5^{\prime}$-TCC TCC GCT TAT TGA TAT GC-3'). Bacterial amplification was carried out at 'Mr DNA' (USA) by employing Qiagen HotStarTaq Plus Master Mix Kit (Qiagen, New York, NY, USA) through a thermocycle program consisted of 3 min at $94{ }^{\circ} \mathrm{C}$ for DNA denaturation, accompanied by 28 cycles of $30 \mathrm{~s}$ at $94^{\circ} \mathrm{C}, 40 \mathrm{~s}$ primer annealing at $53^{\circ} \mathrm{C}$ and $1 \mathrm{~min}$ DNA extension at $72{ }^{\circ} \mathrm{C}$, and a final 5 -min elongation procedure at $72{ }^{\circ} \mathrm{C}$. Fungal amplicons were obtained by a denaturation step at $95^{\circ} \mathrm{C}$ for $2 \mathrm{~min}, 35$ cycles of $30 \mathrm{~s}$ denaturation at $95^{\circ} \mathrm{C}, 30 \mathrm{sec}$ annealing at $55^{\circ} \mathrm{C}$ and DNA extension at $72{ }^{\circ} \mathrm{C}$ for $1 \mathrm{~min}$, followed by a $10 \mathrm{~min}$ final extension step at $72{ }^{\circ} \mathrm{C}$. Purification of the amplified PCR products was performed by Ampure beads (USA). Illumina sequencing was carried out in a MiSeq apparatus and sequencing data was processed through demultiplexing and trimming of the amplicons [30]. Further processing excluded N(s)-containing, abnormal length size ( $<200 \mathrm{bp})$ or low-quality score reads $(Q<30)$ [31]. Using USEARCH v.11, the -fastq_filter was employed to improve the quality of the assembled sequences and the -fastx_uniques option was used to select the unique read sequences and their abundances [32]. Clustering of the selected read sequences into operational taxonomic units (OTUs) (number of read sequences $\geq 3$ ) was performed through the use of the -cluster_otus command. Chimeric sequences were discarded by using the -unoise 3 option of USEARCH v.11 [33]. Taxonomy was assigned to RDP (Ribosomal Database Project) via SPINGO (Species-level IdentificatioN of metaGenOmic amplicons) algorithm [34]. The 16S rRNA gene copies of the genomes of the bacterial taxa detected in the present study were estimated by using rrnDB version 5.5 [35]. AmpliTAXO within AmpliSAS was employed for clustering fungal reads [36]. The microbial community established in the immobilized cell bioreactor under steady state conditions was evaluated through three independent samplings. A total of 137,244 non-chimeric bacterial amplicons (three replicates of $45,764,48,249$ and 43,231 each) and a total of 184,850 non-chimeric fungal amplicons (three replicates of $62,247,65,934$ and 56,669 each) were sequenced and further deposited into the NCBI database under the BioProject number PRJNA530067.

\subsection{Statistical Analysis}

Relationships among variables were identified through calculation of Pearson's correlation coefficients using Past v.3.25 [37], whereas the Student's t-test was implemented to assess significant differences between influent and effluent physicochemical traits. 


\section{Results and Discussion}

\subsection{Operating Behavior and Effectiveness of the Immobilized Cell Biofilter to Degrade} Diclofenac-Based Wastewater

The bioreactor system was fed with synthetic wastewater containing $400 \mathrm{mg} / \mathrm{L}$ of diclofenac in order to reveal the specialized members of the activated sludge, which were capable of breaking down this priority pollutant. Statistically significant differences were found between influent and effluent diclofenac concentrations ( $p<0.01$, in Student's t-test) throughout biofilter operation. A further decrease in effluent diclofenac concentration was observed from days 0-75 to 76-141 $(p<0.01$, in Student's t-test), i.e., from $57.61 \pm 6.21$ to $7.87 \pm 1.84 \mathrm{mg} / \mathrm{L}$ diclofenac. During start-up, an adaptation period of over 2 months was needed in order the microbial biomass to be effectively adapted to the new feeding conditions. Thereafter, diclofenac removal efficiency was highly improved, reaching up to $97.63 \pm 0.62 \%$ (Figure 2), indicating the existence of an effective diclofenac-degrading population in the activated sludge.

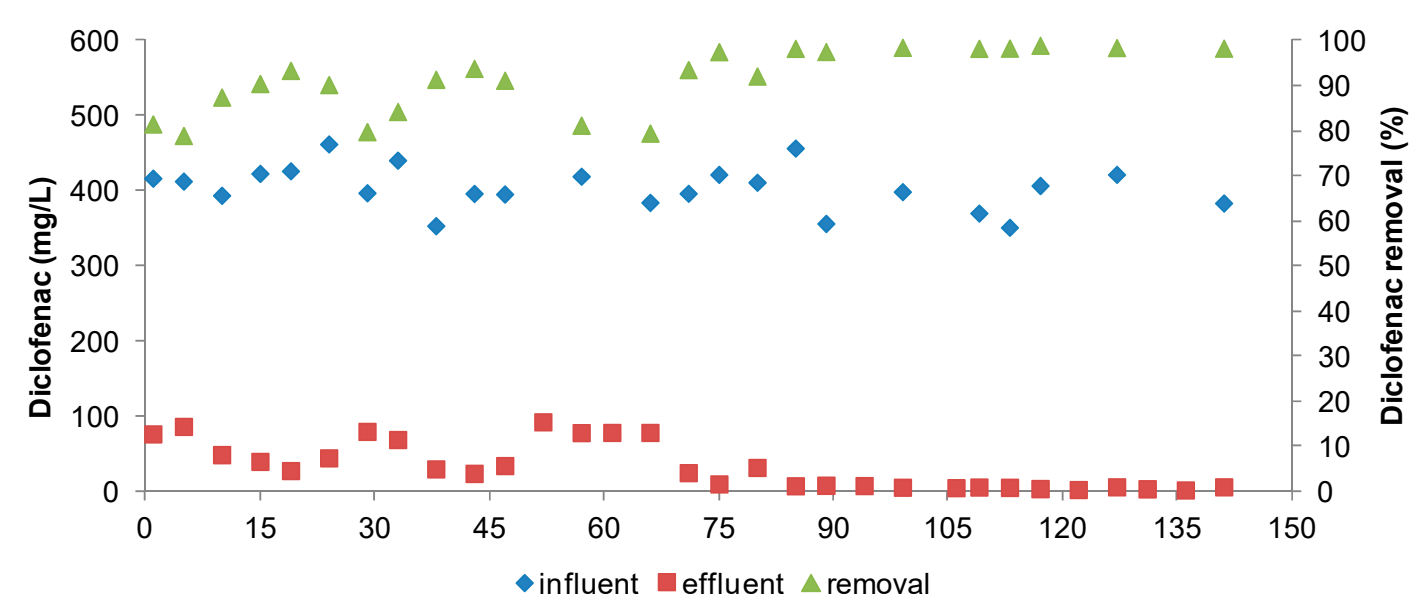

Figure 2. Diclofenac removal pattern in the immobilized cell biofilter treating diclofenac-based wastewater.

Langenhoff et al. [19] used batch reactors containing biomass adapted to high diclofenac concentrations to treat wastewater containing $50 \mathrm{mg} / \mathrm{L}$ diclofenac and reported removal efficiencies of $65-70 \%$ in a 20 day-treatment period, which are much lower than that achieved in the immobilized cell biofilter operated at HRT of 3.5 days. In contrast to batch reactors, the continuous flow mode of operation employed in our study appears to restrict the accumulation of possible toxic metabolites, permitting the progressive development of an acclimatized biomass capable of effectively degrading high diclofenac concentrations at a shorter HRT. In addition, the immobilization of biomass also resulted in elevated biosystem efficiency, due to the fact that the sludge retention time (SRT) was continuously increasing since no biomass was wasted out. According to the literature, SRT values higher than 20 days are needed in order to reach removal efficiencies higher than 50-60\% [10].

Regarding COD removal patterns, the immobilized cell biofilter was adapted in shorter period, resulting in a COD decrease from to $581 \pm 6 \mathrm{mg} / \mathrm{L}$ in the influent to $125 \pm 5 \mathrm{mg} / \mathrm{L}$ in the effluent $(p<0.01$, in Student's t-test), whereas the respective effluent sCOD value was equal to $80.0 \pm 4.6 \mathrm{mg} / \mathrm{L}$ (Figure 3). This COD decline corresponded to COD removal efficiency of $78.5 \pm 0.9$ and $86.2 \pm 0.8 \%$ in the case of total and soluble COD, respectively (Figure 3). The significant correlation between diclofenac concentration decrease and COD removal (correlation coefficient $\mathrm{r}=0.551, p<0.01$ ) points out that both diclofenac and COD removal profiles followed the same trend under steady state conditions. 


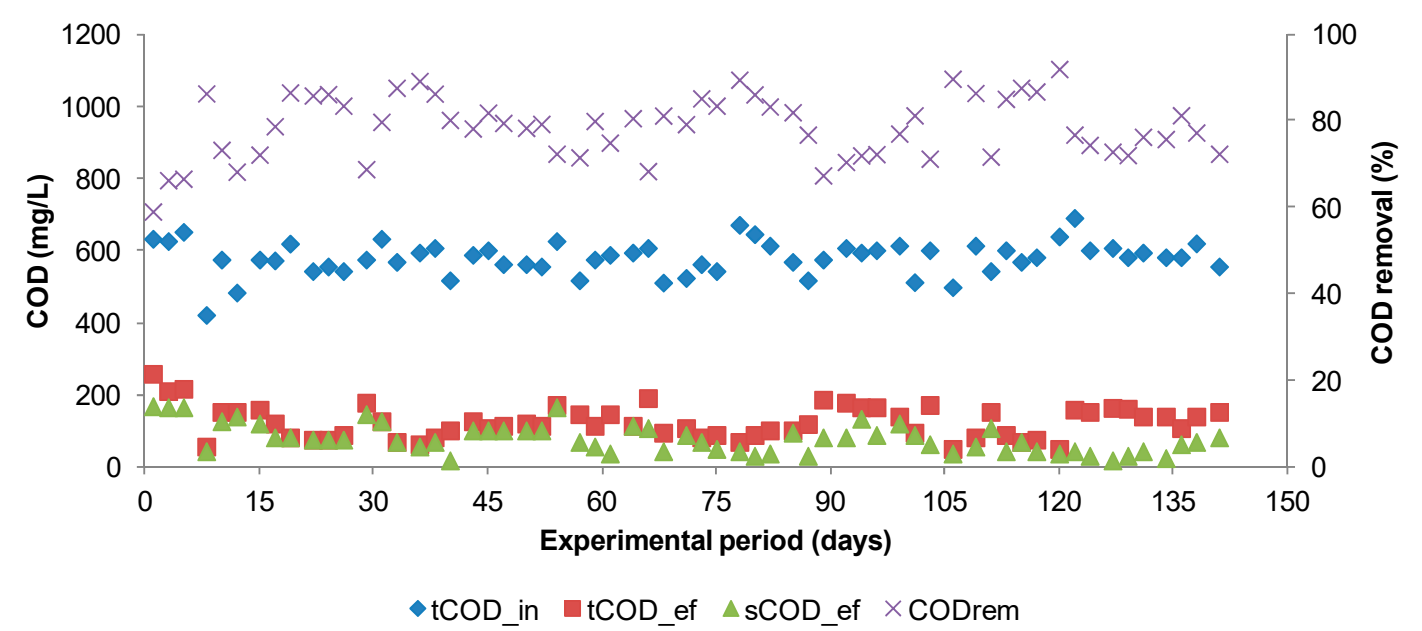

Figure 3. Chemical oxygen demand (COD) removal pattern in the immobilized cell biofilter treating diclofenac-based wastewater.

The $\mathrm{pH}$ in the immobilized cell biofilter was dropped drastically to acidic values $(p<0.01$, in Student t-test) when diclofenac served as the sole carbon and energy source, resulting in a $\mathrm{pH}$ decrease from $7.16 \pm 0.02$ in the influent to $5.67 \pm 0.04$ in the effluent (Figure 4). Moreover, effluent $\mathrm{pH}$ significantly decreased from $5.82 \pm 0.06$ to $5.51 \pm 0.05$ from days $0-75$ to $76-141(p<0.01$, in Student's $\mathrm{t}$-test). Diclofenac removal highly correlated with $\Delta \mathrm{pH}$ (pHin-pHef) $(\mathrm{r}=0.503, p<0.01)$, indicating the influence of diclofenac biodegradation on $\mathrm{pH}$ drop.

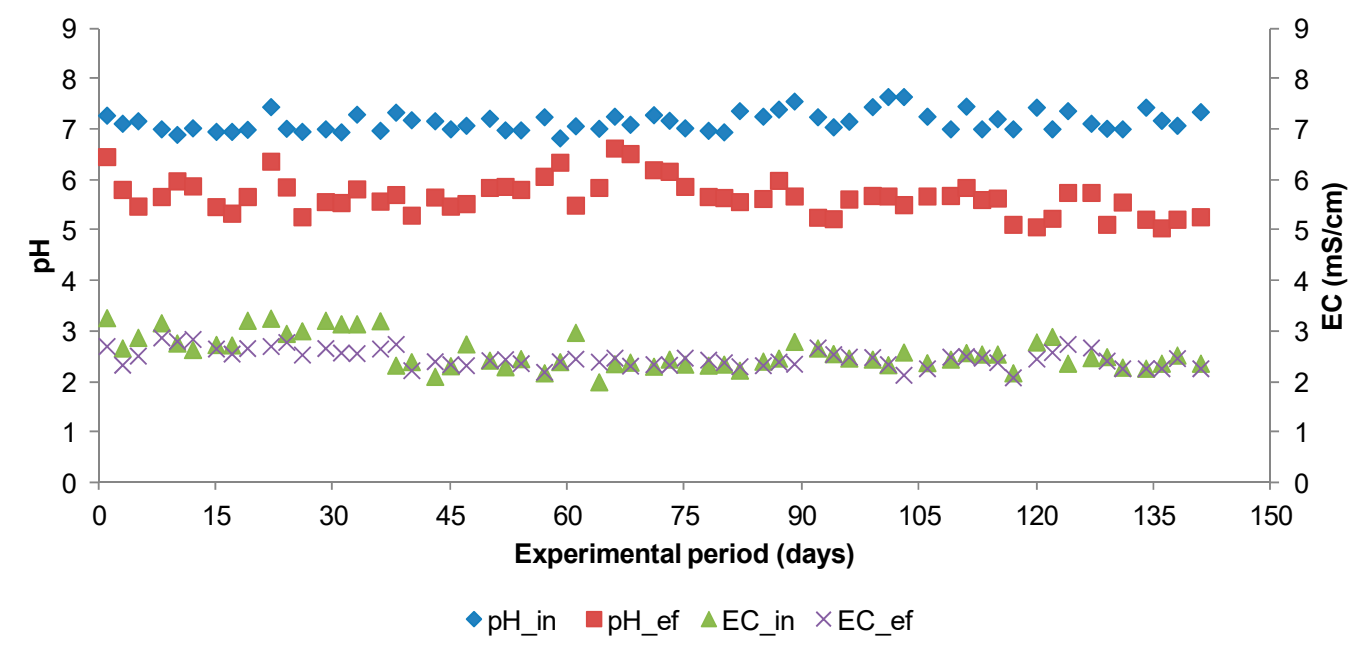

Figure 4. $\mathrm{pH}$ and electrical conductivity (EC) patterns in the immobilized cell biofilter treating diclofenac-based wastewater.

A similar observation was also addressed by Trapido et al. [38], who reported that diclofenac degradation during photolysis led to $\mathrm{pH}$ acidification, independent of the initial $\mathrm{pH}$ value of the diclofenac-containing wastewater. Furthermore, the electrical conductivity (EC) in the influent and the effluent of the biosystem were estimated to be $2.59 \pm 0.04$ and $2.47 \pm 0.02 \mathrm{mS} / \mathrm{cm}$, respectively (Figure 4), due to the fact that the growth medium was supplemented with trace elements. The marginal differences $(p<0.05$, in Student's t-test), which were observed between influent and effluent EC values, could be attributed to the pooled values determined.

Based on the determination of nitrogenous compounds, it appears that the immobilized biomass could not oxidize ammonium to nitrate. A drastic $\mathrm{pH}$ drop to acidic values (below 6) has been reported 
to inhibit nitrifying activity [39]. Besides, differences in metabolic capabilities of specific microbial communities, due to the selection pressure applied by the high diclofenac concentration, cannot be excluded. However, organic nitrogen appeared to be mineralized as proven by the determined TKN and $\mathrm{NH}_{4}{ }^{+}-\mathrm{N}$ values in the influent and the effluent of the biosystem (Table 1), since statistically significant differences were identified between influent and effluent TKN $(p<0.01$, in the Student's t-test).

Table 1. Determination of other physicochemical characteristics in the influent and the effluent of the immobilized cell biofilter treating diclofenac-based wastewater.

\begin{tabular}{ll}
\hline Other Physicochemical Parameters & Mean \pm SE $(\mathbf{n}=\mathbf{6})$ \\
\hline $\mathrm{NH}_{4}{ }^{+}-\mathrm{Nin}(\mathrm{mg} / \mathrm{L})$ & $44.80 \pm 6.62$ \\
$\mathrm{NH}_{4}{ }^{+}-\mathrm{Nef}(\mathrm{mg} / \mathrm{L})$ & $21.00 \pm 6.93$ \\
$\mathrm{TKNin}(\mathrm{mg} / \mathrm{L})$ & $61.60 \pm 2.42$ \\
$\mathrm{TKNef}(\mathrm{mg} / \mathrm{L})$ & $21.56 \pm 3.77$ \\
$\mathrm{PO}_{4}{ }^{3-}-\mathrm{Pin}(\mathrm{mg} / \mathrm{L})$ & $13.17 \pm 1.36$ \\
$\mathrm{PO}_{4}{ }^{3-}-\mathrm{Pef}(\mathrm{mg} / \mathrm{L})$ & $7.07 \pm 1.75$ \\
$\mathrm{NO}_{3}{ }^{-}-\mathrm{Nef}(\mathrm{mg} / \mathrm{L})$ & $1.81 \pm 0.85$ \\
$\mathrm{NO}_{2}{ }^{-}-\mathrm{Nef}(\mathrm{mg} / \mathrm{L})$ & $0.21 \pm 0.12$ \\
$\mathrm{BODef}(\mathrm{mg} / \mathrm{L})$ & $8.00 \pm 1.22$ \\
$\mathrm{DO}(\mathrm{mg} / \mathrm{L})$ & $4.32 \pm 0.22$ \\
\hline
\end{tabular}

This provides evidence for almost complete mineralization of diclofenac, since the $\mathrm{N}$ content of this NSAID was ammonified and its COD was greatly reduced. Even though adequate aeration was provided (4.32 $\pm 0.22 \mathrm{mg} / \mathrm{L})$ since Langenhoff et al. [19] showed that diclofenac degradation was sufficient only under aerobic rather than anoxic conditions, low levels of nitrate and nitrite nitrogen $(1.81 \pm 0.85$ and $0.21 \pm 0.12 \mathrm{mg} / \mathrm{L}$, respectively) were detected as the result of the restricted nitrification process. Indeed, the $\mathrm{N}$ content of diclofenac-based wastewater used was mainly assimilated to the microbial cells rather than nitrified (Table 1). Moreover, sufficient phosphorus concentration was provided in the immobilized cells, determining residual phosphorus concentration in the effluent of $7.07 \pm 1.75 \mathrm{mg} / \mathrm{L}$ (Table 1). As the result of phosphorus assimilation in the biomass, statistically significant differences were found between the influent and effluent $\mathrm{PO}_{4}{ }^{3-}-\mathrm{P}$ concentration $(p<0.05$, in Student's t-test). In addition, the BOD in the effluent of the immobilized cell bioreactor was as low as $8 \mathrm{mg} / \mathrm{L}$ (Table 1).

\subsection{Bacterial Community Structure in the Immobilized Cell Biofilter Fed with Diclofenac-Based Wastewater}

Illumina data revealed that Acidobacteria, Alphaproteobacteria, Gammaproteobacteria and Betaproteobacteria were the predominant higher bacterial taxa $(95.23 \pm 1.24 \%$ of bacterial reads in total), showing almost equal abundances, i.e., $26.49 \pm 0.45 \%, 25.39 \pm 0.40 \%, 22.10 \pm 1.29 \%$ and $21.25 \pm 1.19 \%$ of the total reads, respectively. Actinobacteria also accounted for the $3.05 \pm 0.45 \%$ of the total reads. In addition, amplicon sequencing analysis at genus level showed that the microbial community in the immobilized cell bioreactor fed with diclofenac as the sole carbon and energy source was dominated by bacteria belonging to the genera Granulicella and Rhodanobacter, which accounted for $20.75 \pm 0.56 \%$ and $20.56 \pm 1.59 \%$ of the total reads, respectively (Figure $5 a$ ). In particular, the predominant taxa were associated with the species Granulicella pectinivorans and Rhodanobacter terrae (Figure 5b). Taken into consideration the 16S rRNA gene copies of the genomes of Granulicella and Rhodanobacter, the G. pectinivorans population was double that of R. terrae (Figure 5). Little is known for Granulicella spp., although, as all members of the family Acidobacteriaceae, they are slow growers that are favored by acidic conditions [40] and are capable of utilizing a wide range of carbon sources, even if they are originated from oligotrophic habitants [41]. Rhodanobacter is a common habitant of activated sludge systems [42] and has been reported to be an effective degrader of recalcitrant organic compounds, including volatile organics (VOCs) [43] and other NSAIDs like ibuprofen [44]. Moreover, 
Rhodanobacter is an acid-tolerant denitrifier, which proliferates under acidic conditions [45]. The drop in the effluent $\mathrm{pH}$ can be attributed to the predominance of Acidobacteria and Rhodanobacter in the adapted to high diclofenac concentration biomass, which are common inhabitants of acidic environments, due to their ability to degrade recalcitrant compounds [46], as well as to the fact that bacteria can adjust environmental $\mathrm{pH}$ to their optimum growth [47]. Indeed, the ability of these taxa to utilize a wide range of carbon sources, including recalcitrant organic compounds, and to be effectively adapted under acidic conditions explain their prevalence in the immobilized cell biofilter.

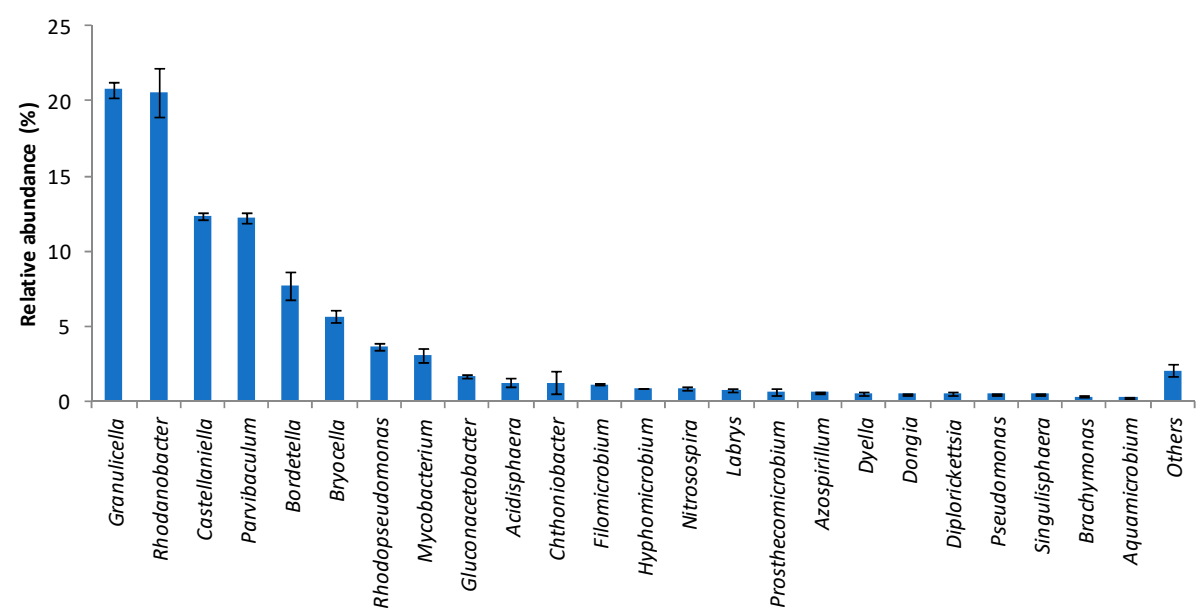

(a)
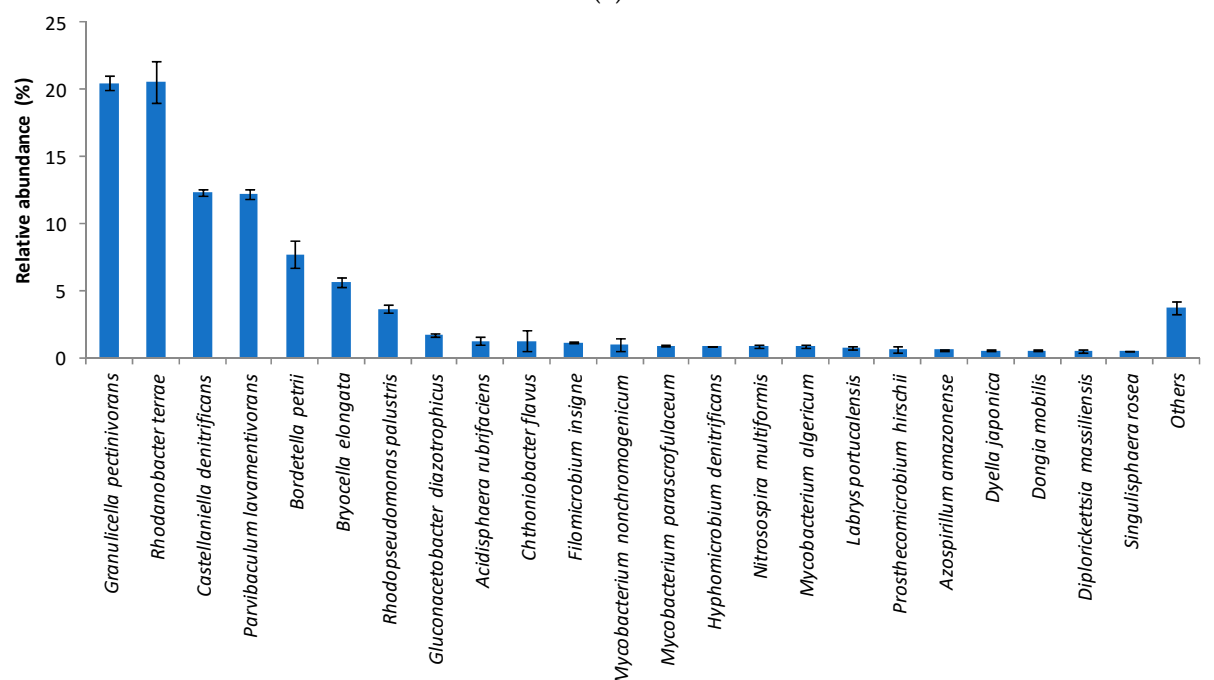

(b)

Figure 5. Relative abundances (\% of total bacterial reads) at (a) genus and (b) species level of the major bacterial taxa in the immobilized cell biofilter treating diclofenac-based wastewater. Taxa with relative abundances below $0.25 \%$ are not reported. Only $0.25 \%$ of the sequences were not assigned to a taxonomically-described species. Genomes' 16S RNA gene copies: Granulicella, 1; Rhodanobacter, 2; Castellaniella, 2; Parvibaculum lavamentivorans, 1; Bordetella petrii, 3; Bryocella; not reported; Rhodopseudomonas palustris, 2; Gluconacetobacter diazotrophicus, 4; Acidisphaera, 1; Chthoniobacter flavus, 1; Filomicrobium, 1; Mycobacterium, 1; Hyphomicrobium denitrificans, 1; Nitrosospira multiformis, 1; Labrys, not reported; Prosthecomicrobium, 1; Azospirillum, 9; Dyella japonica, 2; Dongia, not reported; Diplorickettsia, not reported; Singulisphaera, 8.

Beyond the two most dominant bacterial taxa mentioned above, members of the genera Castellaniella, Parvibaculum, Bordetella and Bryocella, showing relative abundance (as a \% of total bacterial reads) of $12.32 \pm 0.20 \%, 12.19 \pm 0.36 \%, 7.71 \pm 0.97 \%$ and $5.67 \pm 0.38 \%$, respectively, were detected in 
the bacterial community established in the immobilized cell biofilter (Figure 5a). Representatives of Rhodopseudomonas, Mycobacterium, Gluconacetobacter, Acidisphaera, Chthoniobacter and Filomicrobium also corresponded to $12.01 \pm 1.25 \%$ of the total bacterial reads (Figure 5a). To the best of our knowledge, the endophyte Microbacterium sp. MG7 [48], a few soil bacterial strains belonging to Raoultella-Klebsiella group [49,50] and Brevibacterium sp. D4 [25] isolated from activated sludge are the only bacteria that have been found to be capable of degrading diclofenac. In addition, Labrys portucalensis, which was detected in the present study (Figure 5b), has been reported to be capable of completely degrading diclofenac co-metabolically in the presence of acetate [26]. However, no study regarding the diversity of the diclofenac-degrading microbiota, which utilize diclofenac as the sole carbon and energy source, has been performed until now. Moreover, the Alcaligenaceae representatives identified in the immobilized biomass, like Castellaniella denitrificans and Bordetella petrii, which covered $20.03 \pm 1.04 \%$ of the total reads (Figure $5 b$ ), are considered as effective degraders of various recalcitrant compounds [51,52].

Apart from various white-rot fungi like Trametes versicolor, which are considered as effective degraders of endocrine disrupting substances [53,54] and a few other allochnonous fungi [55], no information on fungal microbiota from activated sludge that are capable of degrading diclofenac exists. At phylum/subphylum level, the fungal diversity in the immobilized cell biofilter fed with diclofenac as the sole carbon and energy source consisted almost exclusively of members of Saccharomycotina (Ascomycota), representing $98.54 \pm 0.08 \%$ of the total fungal reads, followed by members of Pezizomycotina, and Ascomycota (1.45 $\pm 0.07 \%$ ) (Figure 6a). Thus, Ascomycota accounted for $99.99 \%$ of the fungal total relative abundance, whereas the remaining $0.01 \%$ consisted of member of the phylum Basidiomycota (subdivisions Pucciniomycotina, Agaricomycotina and Ustilaginomycotina). At the genus level, Wickerhamiella was found to be the predominant fungal taxon in the immobilized cell biofilter with relative abundance of $78.56 \pm 1.35 \%$, followed by Yarrowia $(19.96 \pm 1.28 \%)$, Paecilomyces $(0.94 \pm 0.09 \%)$ and Exophiala $(0.40 \pm 0.05 \%)$ spp. (Figure $6 \mathrm{~b})$.

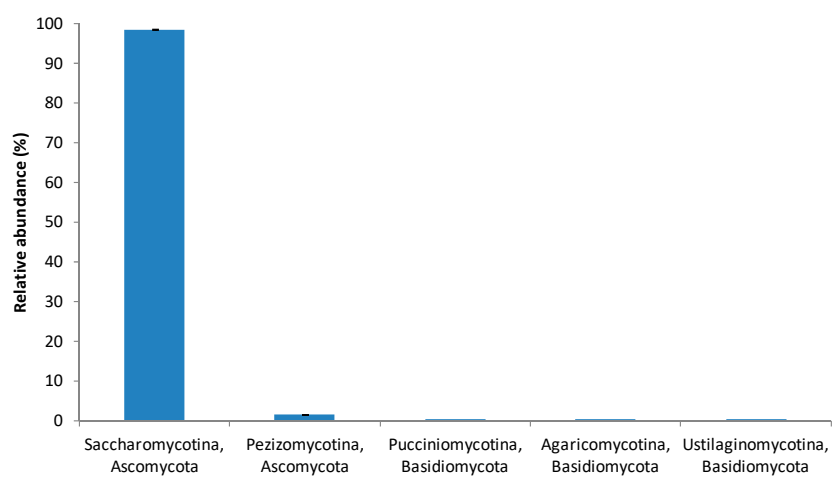

(a)

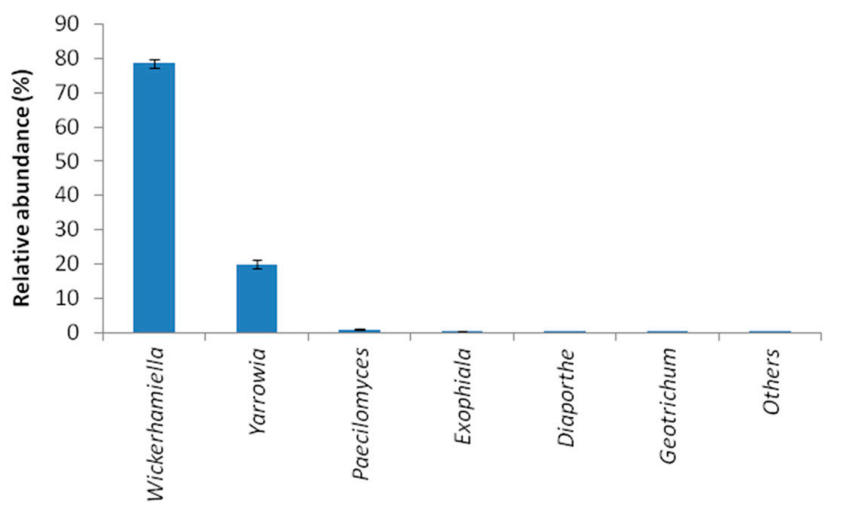

(b)

Figure 6. Relative abundances (\% of total fungal reads) at (a) phylum/subphylum and (b) genus level of the major fungal taxa in the immobilized cell biofilter treating diclofenac-based wastewater. 
Wickerhamiella that was proliferated in the immobilized cell biofilter, where diclofenac served as the sole carbon source, was recently found as the dominant fungal taxon in 18 full-scale municipal WWTPs [56]. Moreover, Yarrowia has been recently reported to possess the capability of partially degrading diclofenac [55], while this is the first report on the potential involvement of Paecilomyces and Exophiala spp. on diclofenac degradation.

It is concluded that regarding the efficiency of the immobilized cell biofilter to degrade diclofenac as the sole carbon and energy source, an adaptation period of over two months under prolonged HRT ( 3.5 days) was required to achieve removal efficiencies as high as $97.63 \pm 0.62 \%$. Afterwards, an effective diclofenac-degrading population was enriched from the activated sludge that was used as the inoculum, where both diclofenac and COD removal patterns followed the same trend under steady state conditions. Utilization of diclofenac as the sole carbon and energy source in the immobilized cell biofilter also led to a drastic $\mathrm{pH}$ decrease. Evidence is also provided for almost complete mineralization of diclofenac, due to the ammonification of $\mathrm{N}$ content of this pollutant and the high COD removal efficiency achieved. Based on amplicon sequencing, the major bacterial taxa identified in the immobilized cell biofilter fed with diclofenac as the sole carbon and energy source were members of the genera Granulicella and Rhodanobacter. The ability of members of these genera to utilize a wide range of carbon sources and to be effectively adapted under acidic conditions were the main factors favoring their prevalence in the immobilized cell biofilter. Wickerhamiella was found to be the predominant fungal taxon in the immobilized cell biofilter, followed by Yarrowia, Paecilomyces and Exophiala. Wickerhamiella is a common fungal taxon in WWTPs, which was also favored in the immobilized cell biofilter when diclofenac served as the sole carbon source.

Author Contributions: E.N. performed the experiments; E.N.; N.R.; P.M.; D.K.; G.T. analyzed the data; E.N. wrote the manuscript; E.N.; N.R.; S.N. drafted and edited the manuscript; S.N. designed and supervised the work.

Funding: This research received no external funding.

Conflicts of Interest: The authors declare no conflicts of interest.

\section{References}

1. Daughton, C.G.; Ternes, T.A. Pharmaceuticals and personal care products in the environment: Agents of subtle change? Environ. Health Perspect. 1999, 107, 907-938. [CrossRef] [PubMed]

2. Ginebreda, A.; Muñoz, I.; Alda, M.L.; Brix, R.; Doval, J.L.; Barceló, D. Environmental risk assessment of pharmaceuticals in rivers: Relationships between hazard indexes and aquatic macroinvertebrate diversity indexes in the Llobregat River (NE Spain). Environ. Int. 2010, 36, 153-162. [CrossRef]

3. Nagler, J.J.; Bouma, J.; Thorgaard, G.H.; Dauble, D.D. High incidence of a male-specific genetic marker in phenotypic female chinook salmon from the Columbia River. Environ. Health Perspect. 2001, 109, 67-69. [CrossRef] [PubMed]

4. Zorita, S.; Martensson, L.; Mathiasson, L. Occurrence and removal of pharmaceuticals in a municipal sewage treatment system in the South of Sweden. Sci. Total Environ. 2009, 407, 2760-2770. [CrossRef] [PubMed]

5. Lonappan, L.; Brar, S.K.; Das, R.K.; Verma, M.; Rao, Y. Diclofenac and its transformation products: Environmental occurrence and toxicity. Environ. Int. 2016, 96, 127-138. [CrossRef]

6. Al-Rajab, A.J.; Sabourin, L.; Lapen, D.R.; Topp, E. The non-steroidal anti-inflammatory drug diclofenac is readily biodegradable in agricultural soils. Sci. Total Environ. 2010, 409, 78-82. [CrossRef] [PubMed]

7. Fernández, C.; González-Doncel, M.; Pro, J.; Carbonell, G.; Tarazona, J.V. Occurrence of pharmaceutically active compounds in surface waters of the Henares-Jarama-Tajo river system (Madrid, Spain) and a potential risk characterization. Sci. Total Environ. 2010, 408, 543-551. [CrossRef] [PubMed]

8. Heberer, T.; Schmidt-Baumler, K.; Stan, H.J. Occurrence and distribution of organic contaminants in the aquatic system in Berlin. Part I: Drug residues and other polar contaminants in Berlin surface and groundwater. Acta Hydrochim. Hydrobiol. 1998, 26, 272-278. [CrossRef]

9. Rabiet, M.; Togola, A.; Brissaud, F.; Seidel, J.L.; Budzinski, H.; Elbaz-Poulichet, F. Consequences of treated water recycling as regards pharmaceuticals and drugs in surface and ground waters of a medium-sized Mediterranean catchment. Environ. Sci. Technol. 2006, 40, 5282-5288. [CrossRef] 
10. Zhang, Y.; Geißen, S.-U.; Gal, C. Carbamazepine and diclofenac: Removal in wastewater treatment plants and occurrence in water bodies. Chemosphere 2008, 73, 1151-1161. [CrossRef]

11. Commission Implementing Decision (EU) 2015/495. Establishing a Watch List of Substances for Union-Wide Monitoring in the Field of Water Policy Pursuant to Directive 2008/105/EC of the European Parliament and of the Council. Off. J. Eur. Union 2015, L 78/40.

12. Directive 2008/105/EC. Directive 2008/105/EC of the European Parliament and of the Council of 16 December 2008 on Environmental Quality Standards in the Field of Water Policy, Amending and Subsequently Repealing Council Directives 82/176/EEC, 83/513/EEC, 84/156/EEC, 84/491/EEC, 86/280/EEC and Amending Directive 2000/60/EC of the European Parliament and of the Council. Off. J. Eur. Union 2008, L 348/84.

13. Liu, J.; Lu, G.; Xie, Z.; Zhang, Z.; Li, S.; Yan, Z. Occurrence, bioaccumulation and risk assessment of lipophilic pharmaceutically active compounds in the downstream rivers of sewage treatment plants. Sci. Total Environ. 2015, 511, 54-62. [CrossRef] [PubMed]

14. Damasceno de Oliveira, L.L.; Nunes, B.; Antunes, S.C.; Campitelli-Ramos, R.; Rocha, O. Acute and chronic effects of three pharmaceutical drugs on the tropical freshwater cladoceran Ceriodaphnia silvestrii. Water Air Soil Pollut. 2018, 229, 116. [CrossRef]

15. Oaks, J.L.; Gilbert, M.; Virani, M.Z.; Watson, R.T.; Meteyer, C.U.; Rideout, B.A.; Shivaprasad, H.L.; Ahmed, S.; Chaudhry, M.J.I.; Arshad, M.; et al. Diclofenac residues as the cause of vulture population decline in Pakistan. Nature 2004, 427, 630-633. [CrossRef] [PubMed]

16. Fatta-Kassinos, D.; Hapeshi, E.; Achilleos, A.; Meric, S.; Gros, M.; Petrovic, M.; Barcelo, D. Existence of pharmaceutical compounds in tertiary treated urban wastewater that is utilized for reuse applications. Water Resour. Manag. 2011, 25, 1183-1193. [CrossRef]

17. Lonappan, L.; Pulicharla, R.; Rouissi, T.; Brar, S.K.; Vermab, M.; Surampallic, R.Y.; Valero, J.R. Diclofenac in municipal wastewater treatment plant: Quantification using laser diode thermal desorption-atmospheric pressure chemicalionization-tandem mass spectrometry approach in comparison with an established liquid chromatography-electrosprayionization-tandem mass spectrometry method. J. Chromatogr. A 2016, 1433, 106-113.

18. Klavarioti, M.; Mantzavinos, D.; Kassinos, D. Removal of residual pharmaceuticals from aqueous systems by advanced oxidation processes. Environ. Int. 2009, 35, 402-417. [CrossRef]

19. Langenhoff, A.; Inderfurth, N.; Veuskens, T.; Schraa, G.; Blokland, M.; Kujawa-Roeleveld, K.; Rijnaarts, H. Microbial removal of the pharmaceutical compounds ibuprofen and diclofenac from wastewater. BioMed Res. Int. 2013, 2013, 325806. [CrossRef]

20. Liu, Y.J.; Lo, S.L.; Liou, Y.H.; Hu, C.Y. Removal of nonsteroidal anti-inflammatory drugs (NSAIDs) by electrocoagulation-flotation with a cationic surfactant. Sep. Purif. Technol. 2015, 152, 148-154. [CrossRef]

21. Pereira, A.M.P.T.; Silva, L.J.G.; Meisel, L.M.; Lino, C.M.; Pena, A. Environmental impact of pharmaceuticals from Portuguese wastewaters: Geographical and seasonal occurrence, removal and risk assessment. Environ. Res. 2015, 136, 108-119. [CrossRef] [PubMed]

22. Behera, S.K.; Kim, H.W.; Oh, J.-E.; Park, H.-S. Occurrence and removal of antibiotics, hormones and several other pharmaceuticals in wastewater treatment plants of the largest industrial city of Korea. Sci. Total Environ. 2011, 409, 4351-4360. [CrossRef] [PubMed]

23. Clara, M.; Strenn, B.; Gans, O.; Martinez, E.; Kreuzinger, N.; Kroiss, H. Removal of selected pharmaceuticals, fragrances and endocrine disrupting compounds in a membrane bioreactor and conventional wastewater treatment plants. Water Res. 2005, 39, 4797-4807. [CrossRef] [PubMed]

24. Gurung, K.; Chaker Ncibi, M.; Sillanpää, M. Assessing membrane fouling and the performance of pilot-scale membrane bioreactor (MBR) to treat real municipal wastewater during winter season in Nordic regions. Sci. Total Environ. 2017, 579, 1289-1297. [CrossRef] [PubMed]

25. Bessa, V.S.; Moreira, I.S.; Tiritan, M.E.; Castro, P.M.L. Enrichment of bacterial strains for the biodegradation of diclofenac and carbamazepine from activated sludge. Int. Biodeterior. Biodegrad. 2017, 120, 135-142. [CrossRef]

26. Moreira, I.S.; Bessa, V.S.; Murgolo, S.; Piccirillo, C.; Mascolo, G.; Castro, P.M.L. Biodegradation of diclofenac by the bacterial strain Labrys portucalensis F11. Ecotoxicol. Environ. Saf. 2018, 152, 104-113. [CrossRef] [PubMed] 
27. Rodarte-Morales, A.I.; Feijoo, G.; Moreira, M.T.; Lema, J.M. Biotransformation of three pharmaceutical active compounds by the fungus Phanerochaete chrysosporium in a fed batch stirred reactor under air and oxygen supply. Biodegradation 2012, 23, 145-156. [CrossRef] [PubMed]

28. Atlas, R.M. Handbook of Microbiological Media, 4th ed.; CRC Press, Taylor \& Francis Group: Boca Raton, FL, USA, 2010; p. 63.

29. Clesceri, L.S.; Greenberg, A.E.; Eaton, A.D. Standard Methods for the Examination of Water and Wastewater, 20th ed.; American Public Health Association (APHA): Washington, DC, USA, 1998.

30. Cole, J.R.; Wang, Q.; Fish, J.A.; Chai, B.; McGarrell, D.M.; Sun, Y.; Brown, C.T.; Porras-Alfaro, A.; Kuske, C.R.; Tiedje, J.M. Ribosomal Database Project: Data and tools for high throughput rRNA analysis. Nucleic Acids Res. 2014, 42, D633-D642. [CrossRef] [PubMed]

31. Masella, A.P.; Bartram, A.K.; Truszkowski, J.M.; Brown, D.G.; Neufeld, J.D. PANDAseq: Paired-end assembler for Illumina sequences. BMC Bioinform. 2012, 13, 31. [CrossRef]

32. Edgar, R.C. SEARCH_16S: A new algorithm for identifying 16S ribosomal RNA genes in contigs and chromosomes. bioRxiv 2017, 124131. [CrossRef]

33. Edgar, R.C. UNOISE2: Improved error-correction for Illumina $16 \mathrm{~S}$ and ITS amplicon sequencing. bioRxiv 2016, 081257. [CrossRef]

34. Allard, G.; Ryan, F.J.; Jeffery, I.B.; Claesson, M.J. SPINGO: A rapid species-classifier for microbial amplicon sequences. BMC Bioinform. 2015, 16, 324. [CrossRef] [PubMed]

35. Stoddard, S.F.; Smith, B.J.; Hein, R.; Roller, B.R.K.; Schmidt, T.M. rrnDB: Improved tools for interpreting rRNA gene abundance in bacteria and archaea and a new foundation for future development. Nucleic Acids Res. 2015, 43, D593-D598. [CrossRef] [PubMed]

36. Sebastian, A.; Herdegen, M.; Migalska, M.; Radwan, J. AmpliSAS: A web server for multilocus genotyping using next-generation amplicon sequencing data. Mol. Ecol. Resour. 2016, 16, 498-510. [CrossRef] [PubMed]

37. Hammer, Ø. PAST-Paleontological Statistics; Version 3.25; Natural History Museum, University of Oslo: Olso, Norway, 2019; Available online: https://folk.uio.no/ohammer/past/index.html (accessed on 6 August 2019).

38. Trapido, M.; Epold, I.; Dulova, N. Degradation of diclofenac in aqueous solution by homogeneous and heterogeneous photolysis. J. Environ. Eng. Ecol. Sci. 2012, 1, 3.

39. Princic, A.; Mahne, I.; Megusar, F.; Paul, E.A.; Tiedje, J.M. Effects of pH and oxygen and ammonium concentrations on the community structure of nitrifying bacteria from wastewater. Appl. Environ. Microbiol. 1998, 64, 3584-3590.

40. Campbell, B.J. The family Acidobacteriaceae. In The Prokaryotes: Other Major Lineages of Bacteria and the Archaea; Rosenberg, E., DeLong, E.F., Lory, S., Stackebrandt, E., Thompson, F., Eds.; Springer: Berlin/Heidelberg, Germany, 2014; pp. 405-415.

41. de Castro, V.H.L.; Schroeder, L.F.; Quirino, B.F.; Kruger, R.H.; Barreto, C.C. Acidobacteria from oligotrophic soil from the Cerrado can grow in a wide range of carbon source concentrations. Can. J. Microbiol. 2013, 59, 746-753. [CrossRef]

42. Aqeel, H.; Basuvaraj, M.; Hall, M.; Neufeld, J.D.; Liss, S.N. Microbial dynamics and properties of aerobic granules developed in a laboratory-scale sequencing batch reactor with an intermediate filamentous bulking stage. Appl. Microbiol. Biotechnol. 2016, 100, 447-460. [CrossRef]

43. Yoshikawa, M.; Zhang, M.; Kurisu, F.; Toyota, K. Bacterial degraders of coexisting dichloromethane, benzene, and toluene, identified by stable-isotope probing. Water Air Soil Pollut. 2017, 228, 418. [CrossRef]

44. Navrozidou, E.; Melidis, P.; Ntougias, S. Biodegradation aspects of ibuprofen and identification of ibuprofen-degrading microbiota in an immobilized cell bioreactor. Environ. Sci. Pollut. Res. 2019, 26, 14238-14249. [CrossRef]

45. Green, S.J.; Prakash, O.; Jasrotia, P.; Overholt, W.A.; Cardenas, E.; Hubbard, D.; Tiedje, J.M.; Watson, D.B.; Schadt, C.W.; Brooks, S.C.; et al. Denitrifying bacteria from the genus Rhodanobacter dominate bacterial communities in the highly contaminated subsurface of a nuclear legacy waste site. Appl. Environ. Microbiol. 2012, 78, 1039-1047. [CrossRef] [PubMed]

46. Song, M.; Jiang, L.; Zhang, D.; Luo, C.; Wang, Y.; Yu, Z.; Yin, H.; Zhang, G. Bacteria capable of degrading anthracene, phenanthrene, and fluoranthene as revealed by DNA based stable-isotope probing in a forest soil. J. Hazard. Mater. 2016, 308, 50-57. [CrossRef] [PubMed]

47. Ratzke, C.; Gore, J. Modifying and reacting to the environmental pH can drive bacterial interactions. PLoS Biol. 2018, 16, e2004248. [CrossRef] [PubMed] 
48. Wegrzy, A.; Felis, E. Isolation of bacterial endophytes from Phalaris arundinacea and their potential in diclofenac and sulfamethoxazole degradation. Pol. J. Microbiol. 2018, 67, 321-331. [CrossRef] [PubMed]

49. Palyzová, A.; Zahradník, J.; Marešová, H.; Sokolová, L.; Kyslíková, E.; Grulich, M.; Štěpánek, V.; Řezanka, T.; Kyslík, P. Potential of the strain Raoultella sp. KDF8 for removal of analgesics. Folia Microbiol. 2018, 63, 273-282. [CrossRef] [PubMed]

50. Stylianou, K.; Hapeshi, E.; Vasquez, M.I.; Fatta-Kassinos, D.; Vyrides, I. Diclofenac biodegradation by newly isolated Klebsiella sp. KSC: Microbial intermediates and ecotoxicological assessment. J. Environ. Chem. Eng. 2018, 6, 3242-3248. [CrossRef]

51. Cycon, M.; Mrozik, A.; Piotrowska-Seget, Z. Bioaugmentation as a strategy for the remediation of pesticide-polluted soil: A review. Chemosphere 2017, 172, 52-71. [CrossRef]

52. Stolz, A.; Bürger, S.; Kuhm, A.; Kämpfer, P.; Busse, H.-J. Pusillimonas noertemannii gen. nov., sp. nov., a new member of the family Alcaligenaceae that degrades substituted salicylates. Int. J. Syst. Evol. Microbiol. 2005, 55, 1077-1081. [CrossRef] [PubMed]

53. Castellet-Rovira, F.; Lucas, D.; Villagrasa, M.; Rodríguez-Mozaz, S.; Barceló, D.; Sarrà, M. Stropharia rugosoannulata and Gymnopilus luteofolius: Promising fungal species for pharmaceutical biodegradation in contaminated water. J. Environ. Manag. 2018, 207, 396-404. [CrossRef]

54. Cruz-Morató, C.; Lucas, D.; Llorca, M.; Rodriguez-Mozaz, S.; Gorga, M.; Petrovic, M.; Barceló, D.; Vicent, T.; Sarrà, M.; Marco-Urrea, E. Hospital wastewater treatment by fungal bioreactor: Removal efficiency for pharmaceuticals and endocrine disruptor compounds. Sci. Total Environ. 2014, 493, 365-376. [CrossRef]

55. Aracagök, Y.D.; Göker, H.; Cihangir, N. Biodegradation of diclofenac with fungal strains. Arch. Environ. Prot. 2018, 44, 55-62.

56. Niu, L.; Li, Y.; Xu, L.; Wang, P.; Zhang, W.; Wang, C.; Cai, W.; Wang, L. Ignored fungal community in activated sludge wastewater treatment plants: Diversity and altitudinal characteristics. Environ. Sci. Pollut. Res. 2017, 24, 4185-4193. [CrossRef] [PubMed]

(C) 2019 by the authors. Licensee MDPI, Basel, Switzerland. This article is an open access article distributed under the terms and conditions of the Creative Commons Attribution (CC BY) license (http://creativecommons.org/licenses/by/4.0/). 